\title{
INFLUENCE OF SEROTONERGIC TRANSMISSION AND POSTSYNAPTIC 5-HT2C ACTION ON THE FEEDING BEHAVIOR OF Coturnix japonica (GALLIFORMES: AVES)
}

\author{
CEDRAZ-MERCEZ, P. L. ${ }^{1}$, ALMEIDA, A. C. ${ }^{2}$, COSTA-E-SOUSA, R. H. ${ }^{3}$, \\ BADAUÊ-PASSOS JR., D. ${ }^{4}$, CASTILHOS, L. R. ${ }^{5}$, OLIVARES, E. L. ${ }^{6}$, \\ MARINHO JR, A. ${ }^{6}$, MEDEIROS, M. A. ${ }^{6}$ and REIS, L. C. ${ }^{6}$ \\ 'FAPERJ \\ ${ }^{2}$ PIBIC/CNPq, Depto. de Ciências Fisiológicas/IB/UFRuralRJ \\ ${ }^{3}$ Instituto de Biofísica Carlos Chagas Filho/UFRJ \\ ${ }^{4}$ Faculdade de Medicina de Ribeirão Preto/USP \\ ${ }^{5}$ Faculdade de Medicina Veterinária e Zootecnia/USP \\ ${ }^{6}$ Departamento de Ciências Fisiológicas/IB/UFRuralRJ \\ Correspondence to: Luís Carlos Reis, DCF/IB/UFRuralRJ, CEP 23890-000, \\ BR 465, Km 07, Seropédica, RJ, Brazil, e-mail: lcreis@ufrrj.br \\ Received November 19, 2003 - Accepted June 14, 2004 - Distributed November 30, 2005
}

(With 5 figures)

\begin{abstract}
We investigated the role of 5-HT2C receptors and serotonergic transmission in the feeding behavior control of quails. Administration of serotonin releaser, fenfluramine (FEN) and 5-HT2C agonists, mCPP and MK212, 1.0 and $3.3 \mathrm{mg} / \mathrm{Kg}$ induced significant inhibition of food intake in previously fasted fowls $(0.71 \pm 0.18 \mathrm{~g}$ and $0.47 \pm 0.2 \mathrm{~g} ; 0.49 \pm 0.22 \mathrm{~g}$ and $0.48 \pm 0.29 \mathrm{~g} ; 0.82 \pm 0.13 \mathrm{~g}$ and $0.71 \pm 0.16 \mathrm{~g}$, respectively). Control groups ranged from $2.89 \pm 0.21 \mathrm{~g}$ to $2.97 \pm 0.22 \mathrm{~g}, 60 \mathrm{~min}$ after reintroduction of food, $\mathrm{P}<0.0001)$. Similar results were obtained with normally fed quails. Both serotonin releaser and 5-HT2C agonists, in a $3.3 \mathrm{mg} / \mathrm{Kg}$ dose, induced hypophagy (FEN, $0.78 \pm 0.08 \mathrm{~g}$; mCPP, $0.89 \pm 0.07 \mathrm{~g}$; MK212, $1.25 \pm 0.17 \mathrm{~g} v \mathrm{~s}$. controls, $2.05 \pm 0.12 \mathrm{~g}, 120 \mathrm{~min}$ after food was presented, $\mathrm{P}<0.0001$ to $\mathrm{P}<0.01)$. Previous administration of 5-HT2C antagonist, LY53857 $(5.0 \mathrm{mg} / \mathrm{Kg})$ blocked the hypophagic response induced by $5-\mathrm{HT} 2 \mathrm{C}$ agonists $60 \mathrm{~min}$ after food was reintroduced. Current data show a modulatory role of serotonin release and postsynaptic 5-HT2C receptors in the feeding behavior of quails.
\end{abstract}

Keywords: serotonergic transmission, serotonin release, 5-HT2C receptors, food intake, quails, Coturnix japonica.

\section{RESUMO}

\section{Influência da transmissão serotonérgica e da ação 5-HT2C pós-sináptica no comportamento alimentar em Coturnix japonica (Galliformes: Aves)}

Investigamos nesse estudo o papel dos receptores 5-HT2C e da transmissão serotonérgica no controle do comportamento alimentar em codornas. Em grupo de aves em jejum, a administração do liberador de serotonina, fenfluramina (FEN) e dos agonistas 5-HT2C, mCPP e MK212, nas doses de 1,0 e 3,3 mg/Kg induziu a uma redução significativa da ingestão alimentar $(0,71 \pm 0,18 \mathrm{~g}$ e $0,47 \pm 0,2 \mathrm{~g} ; 0,49 \pm 0,22 \mathrm{~g}$ e $0,48 \pm 0,29 \mathrm{~g} ; 0,82 \pm 0,13 \mathrm{~g}$ e $0,71 \pm 0,16 \mathrm{~g}$; respectivamente). A ingestão de alimento nos grupos controles variou de 2,89 $\pm 0,21 \mathrm{~g}$ a 2,97 $\pm 0,22 \mathrm{~g}, 60$ min após a reapresentação de alimento, $\mathrm{P}<0,0001)$. Resultados similares foram obtidos com as codornas normoalimentadas. Tanto o liberador de serotonina, FEN, quanto os agonistas 5-HT2C, mCPP e MK212 em doses de 3,3 mg/Kg induziram resposta hipofágica (FEN, 0,78 \pm 0,08 g; mCPP, 0,89 \pm 0,07 g; MK212, 1,25 \pm 0,17 g vs. controles, 2,05 \pm 0,12 g, 120 min após a oferta de alimento, $\mathrm{P}<0.0001$ a $\mathrm{P}<0.01$ ). A administração prévia do antagonista 5-HT2C, LY53857 $(5,0 \mathrm{mg} / \mathrm{Kg})$ bloqueou a resposta hipofágica induzida pelos agonistas 5-HT2C, 60 min após a apresentação 
de alimento. Os resultados obtidos demonstram o papel modulatório da liberação de serotonina e dos receptores pós-sinápticos 5-HT2C, no controle do comportamento alimentar de codornas.

Palavras-chave: transmissão serotonérgica, liberação de serotonina, receptores 5-HT2C, ingestão de alimento, codornas, Coturnix japonica.

\section{INTRODUCTION}

Previous studies involving mammals, particularly murines, implicated the brain serotonergic system in the control of appetite and satiety. Early investigations in this field showed that increased circulating tryptophan availability (initial precursor of serotonin synthesis), and the subsequent increasing brain serotonin content, constitute physiological parameters for activation of satiety and modulation of appetite (Fernstrom \& Wurtman, 1971a, 1971b; Fernstrom, 1983; Tyce, 1990). Feeding response in rats is accompanied by an increase in serotonin release in the lateral hypothalamic area, a region involved with coordination of feeding behavior (Shimizu et al., 1992).

The participation of 5-HT2C and 5-HT1B receptors is a widely accepted notion in the anorectic response in several paradigms (Blundell, 1984; Blundell \& Hill, 1987; Curzon, 1990; Halford et al., 1997). Involvement of serotonergic transmission demonstrated by treatment with serotonin releasers has also confirmed that system's modulatory influence on feeding behavior (Blundell, 1984). On the other hand, inhibition of the firing rate of raphe serotonergic neurons and the resulting decrease of ascending transmission elicit hyperphagy (Dourish et al., 1986; Hutson et al., 1986, 1988; Aghajanian et al., 1990; Curzon, 1990, 1991).

A few reports have shown a physiological correlation between serotonergic system activity and control of feeding behavior in birds (Rosebrough, 1996; Steffens et al., 1997; Thomaz et al., 1998; Saadoun \& Cabrera, 2002; Reis et al., 2005).

Traits of serotonergic control of the feeding behavior are probably already present to a high degree in birds, since the topographical and functional organization of the serotonergic system preserves similarities with that of reptiles and mammals (Dubé \& Parent, 1981; Parent, 1981; Parent et al., 1981; Duchala et al., 1984; Sako et al., 1986; Cozzi et al., 1991; Challet et al., 1996; Gruss \& Braun, 1997). Nevertheless, the biochemical, pharmacological and behavioral characterization of serotonin receptors has been little investigated (Gleeson et al., 1992; Saadoun \& Cabrera, 2002).

Studies of the participation of 5-HT2C receptors and serotonin release in the control of feeding behavior have not been reported, although binding sites in bird brains for classical serotonergic agonists have been described (Stephenson \& Andrew, 1994; Saadoun \& Cabrera, 2002).

Observations in our laboratory revealed evidence of serotonergic involvement in the control of quail feeding behavior (Reis et al., 2005). In this report, we demonstrate that dietary supplementation of tryptophan (initial precursor of serotonin synthesis) inhibits food intake, although a much larger concentration than that required to produce the same anorectic response in mammals is necessary.

When 5-hydroxy-tryptophan, the immediate precursor of serotonin synthesis, was administered by the systemic route, the response elicited was hypophagy associated with intense thirst. However, the role of synaptic transmission and the relevance of the postsynaptic action of serotonin releasers and serotonergic agonists on the feeding behavior of quails are still unknown.

Thus, this paper examines the influence of treatment with the serotonin releasers fenfluramine and 5-HT2C agonists mCPP and MK212 on the feeding behavior of fasted and normally fed quails.

\section{MATERIALS AND METHODS}

\section{Animals and materials used}

Adult male quails weighing 130-160 g were kept in special cages equipped with drinking fountains and individual food containers. Throughout the birds' adaptation period to the laboratory conditions they had ad libitum access to food and water (Purina, 20\% raw protein for quails) and were exposed to a $12 / 12 \mathrm{~h}$ light/dark cycle and a room temperature of 25 to $30{ }^{\circ} \mathrm{C}$. Food intake was evaluated with a precision electronic scale. The drugs used here, i.e., fenfluramine, releaser 
of serotonin (FEN) (Sigma-Aldrich, USA) and mCPP [1-(3-chlorophenyl) piperazine] (Research Biochemical Inc., USA) and MK212 [6-chloro-2(1-piperazinil) pyrazine] (Merck Sharp \& Dohme, USA), 5-HT2C agonists were all administered by subcutaneous $(\mathrm{sc})$ route $30 \mathrm{~min}$ before food was offered. The 5-HT2C antagonist LY53857 (Eli Lilly, USA) was administered $30 \mathrm{~min}$, sc, before injection of the 5-HT2C agonists.

\section{Experimental procedures}

Influence of the treatment with serotonin releaser FEN and the 5-HT2C agonists $m C P P$ and MK212 on the food intake of fasted quails

The birds were fasted from 7:00 to 13:00 h, at which time they were fed. Food intake was measured during $60 \mathrm{~min}$. To evaluate the influence of serotonin release on the birds' feeding behavior, they were given doses of $1.0(\mathrm{~N}=10)$ and $3.3 \mathrm{mg} / \mathrm{Kg}(\mathrm{N}=10)$ of FEN. The influence the of 5-HT2C receptors on the food intake behavior was evaluated by treating the birds with doses of $1.0(\mathrm{~N}=10)$ and $3.3 \mathrm{mg} / \mathrm{Kg}$ $(\mathrm{N}=12)$ of $\mathrm{mCPP}$ and with doses of $1.0(\mathrm{~N}=10)$ and $3.3 \mathrm{mg} / \mathrm{Kg}(\mathrm{N}=12)$ of MK212. The control groups for all conditions were treated with isotonic saline $(0.1 \mathrm{~mL} / 100 \mathrm{~g})(\mathrm{N}=10)$.

Influence of the treatment with serotonin releaser FEN or 5-HT2C agonists $\mathrm{mCPP}$ and MK212 on the food intake of normally fed quails

Food intake was also evaluated in a group of normally fed birds treated with a dose of $3.3 \mathrm{mg} / \mathrm{Kg}$ ( $\mathrm{N}=10$ for each group) of FEN, mCPP and MK212 for $120 \mathrm{~min}$. A control group of normally fed quails was treated with saline $(0.1 \mathrm{~mL} / 100 \mathrm{~g})(\mathrm{N}=11)$.

\section{Influence of previous treatment with 5-HT2C} antagonist LY53857 on the food intake of normally fed quails

In this condition, 5-HT2C antagonist LY53857 $(5.0 \mathrm{mg} / \mathrm{Kg})$ was administered $30 \mathrm{~min}$ before $\mathrm{mCPP}$ (3.3 mg/Kg, $\mathrm{N}=10$ ) and MK212 (3.3 mg/Kg, $\mathrm{N}=11$ ) injections. Other groups were formed and received only saline $(\mathrm{N}=11), \mathrm{mCPP}, 3.3 \mathrm{mg} / \mathrm{Kg}$ $(\mathrm{N}=10)$ or MK212, $3.3 \mathrm{mg} / \mathrm{Kg}(\mathrm{N}=10)$.

\section{Statistical analysis}

The results of these treatments are expressed as mean \pm standard error. The values obtained were statistically analyzed by ANOVA and Student " $t$ " test. Differences among mean values were considered significant when $\mathrm{P}<0.05$.

\section{RESULTS}

Administration of FEN, mCPP and MK212 in doses of 1.0 and $3.3 \mathrm{mg} / \mathrm{Kg}$ induced a significant decrease of food intake by fasted quails $(0.71 \pm 0.18 \mathrm{~g}$ and $0.47 \pm 0.2 \mathrm{~g} ; 0.49 \pm 0.22 \mathrm{~g}$ and $0.48 \pm 0.29 \mathrm{~g} ; 0.82 \pm 0.13 \mathrm{~g}$ and $0.71 \pm 0.16 \mathrm{~g}$, respectively). The controls groups ranged from $2.89 \pm 0.21 \mathrm{~g}$ to $2.97 \pm 0.22 \mathrm{~g}, 60 \mathrm{~min}$ after food was again offered, $\mathrm{P}<0.0001$ ) (Figs. 1, 2 and 3).

Similar results were obtained with the normally fed quails. Both the serotonin releaser FEN and the 5-HT2C agonists mCPP and MK212, in doses of $3.3 \mathrm{mg} / \mathrm{Kg}$, induced a hypophagic response (FEN, $0.78 \pm 0.08 \mathrm{~g}$; $\mathrm{mCPP}$, $0.89 \pm 0.07 \mathrm{~g}$; MK212, $1.25 \pm 0.17 \mathrm{~g} v$ s. controls, $2.05 \pm 0.12 \mathrm{~g}, 120 \mathrm{~min}$ after food was presented, $\mathrm{P}<0.01$ to $\mathrm{P}<0.0001$ ) (Fig. 4).

A previous injection of the 5-HT2C antagonist LY53857 (5.0 mg/Kg) blocked the hypophagic effect induced by mCPP and MK212, 60 min after food was offered. After $120 \mathrm{~min}$, the blockage was maintained only with the mCPP treatment (Fig. 5).

\section{DISCUSSION}

These results suggest the existence of serotonergic receptors in quails involved in the regulation of feeding behavior mediated by the activation of 5-HT2C receptors. In addition, the results attained with the serotonin releaser FEN indicate that serotonergic transmission is critically involved in the regulation of food intake by quails.

The agonists mCPP and MK212 also elicit an anorectic response in mammals by stimulation of the 5-HT2C receptor (Blundell, 1984; Blundell \& Hill, 1987; Curzon, 1990; Halford et al., 1997). These receptors are distributed in forebrain structures, particularly in the hypothalamus, which are known to be implicated in appetite control. Thus, the anorectic responses achieved with $\mathrm{mCPP}$ and MK212, which are powerful 5-HT2C agonists, provide evidence of the central mediation of appetite by serotonin.

The literature contains no report concerning the distribution and involvement of 5-HT2C receptors in the control of food intake by quails. 


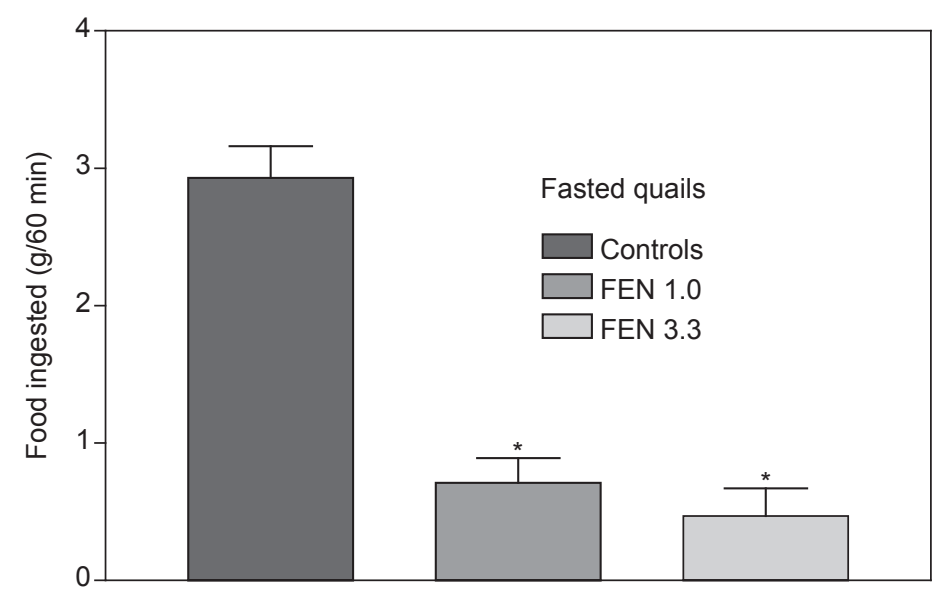

Fig. 1 - Effect of the administration of the serotonin releaser, fenfluramine (FEN, 1.0 and $3.3 \mathrm{mg} / \mathrm{Kg}$, sc), on the food intake of fasted quails. Data represent mean \pm SEM. $* \mathrm{P}<0.0001$ compared with controls.

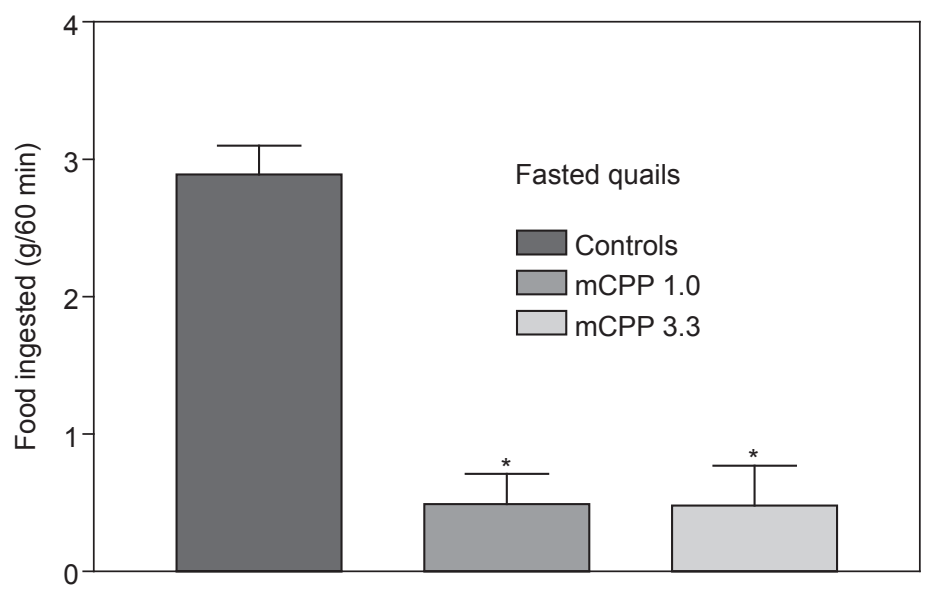

Fig. 2 - Effect of the administration of 5-HT2C serotonin agonist, $\mathrm{mCPP}(1.0$ and $3.3 \mathrm{mg} / \mathrm{Kg}$, sc), on the food intake of fasted quails. Data represent mean \pm SEM. $* \mathrm{P}<0.0001$ compared with controls.

Thus, our data represent the second report of indirect evidence of the involvement of a serotonergic system in the feeding behavior of quails. In the first report, Reis et al. (2005) demonstrated inhibition of food intake by quails treated with initial (tryptophan) and immediate (5-hydroxytryptophan) precursors of serotonin synthesis.

Current observations of the effects of FEN provide further evidence of the role of serotonergic transmission and serotonin release in the modulation of quail feeding behavior. Derivatives of that substance, which are used as anorexics for human obesity control, are also powerful anorexics for other mammals (Blundell, 1984, 1991; Halford \& Blundell, 2000). In this context, FEN has been widely used in humans to ascertain the release of brain serotonin in depressed patients with possible serotonergic hypofunction (Meltzer \& Lowy, 1987).

Data on FEN suggest that the neurotransmission and release system of this indoleamine preserves molecular and functional characteristics found in mammals. The same observations apply to the results achieved with 5-HT2C agonists. Serotonin release and 5-HT2C postsynaptic activation in vertebrates probably constitute 


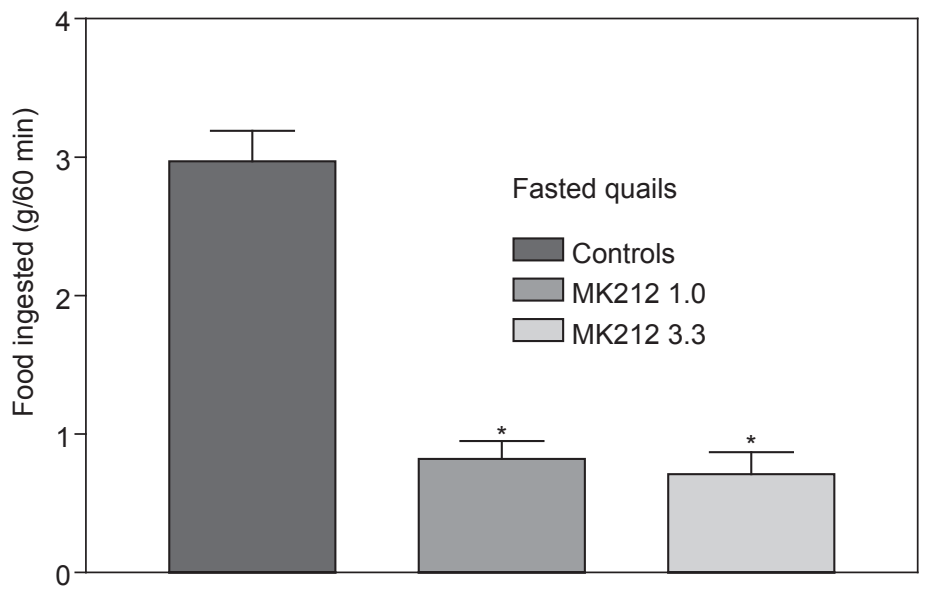

Fig. 3 - Effect of the administration of 5-HT2C serotonin agonist, MK212 (1.0 and $3.3 \mathrm{mg} / \mathrm{Kg}, \mathrm{sc})$, on the food intake of fasted quails. Data represent mean \pm SEM. $* \mathrm{P}<0.0001$ compared to controls.

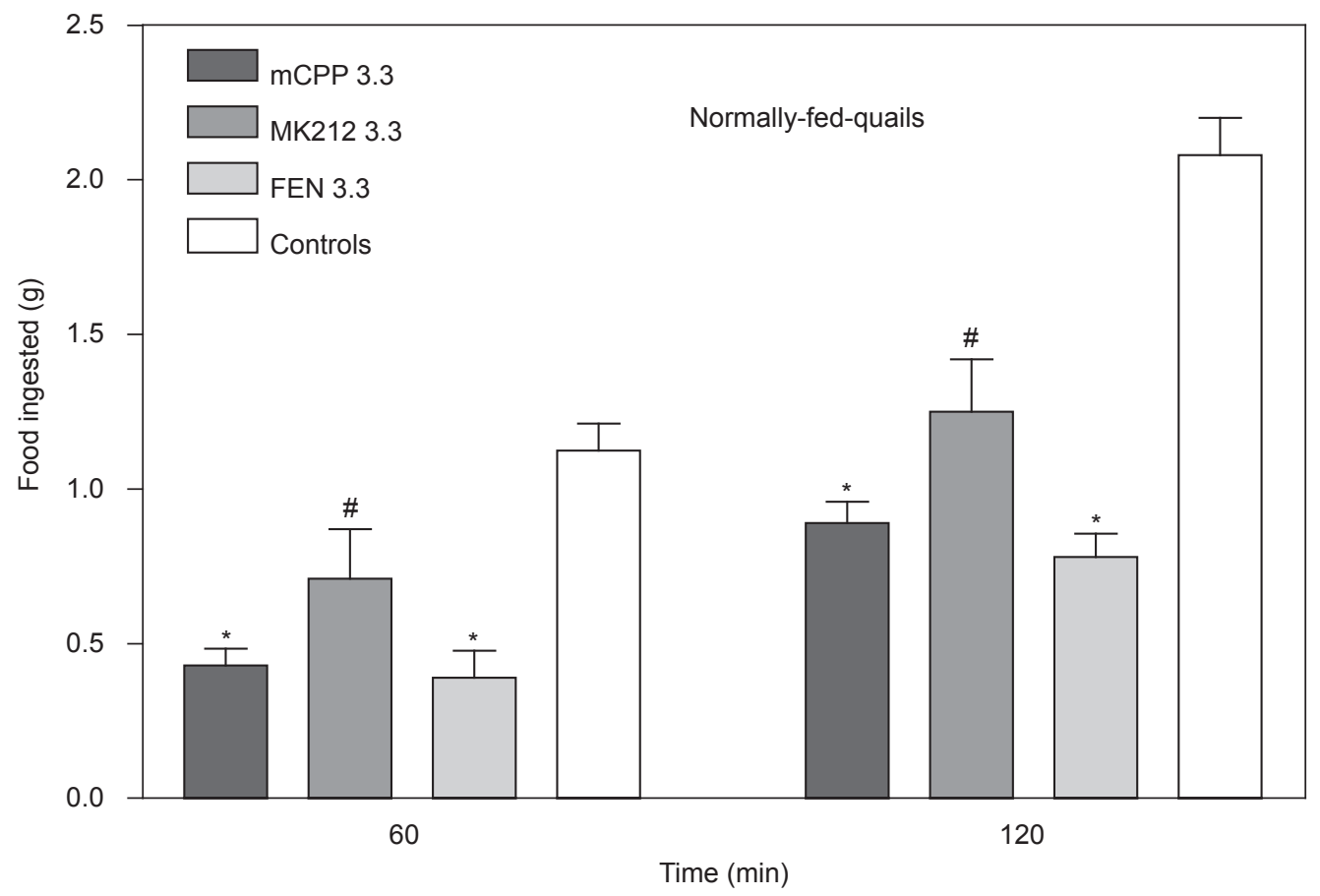

Fig. 4 - Effect of the administration 5-HT2C serotonin agonists, mCPP and MK212 (1.0 and 3.3 mg/Kg, for each agonist, sc), and of serotonin releaser, fenfluramine (FEN, 1.0 and $3.3 \mathrm{mg} / \mathrm{Kg}$, sc), on the food intake of normally fed quails. Data represent mean $\pm \mathrm{SEM}$. $* \mathrm{P}<0.0001$ and $\# \mathrm{P}<0.01$ compared with controls.

neurobiological substrata preserved since their evolutionary beginnings.

Along the evolutionary path, the preservation of molecules in these highly homologous systems possibly means that appetite modulation by serotonin constitutes a homeostatic mechanism that has long been related with the control of energetic equilibrium. This reasoning is compatible with the assumption that topographic and functional phenotypes of the serotonergic system are 


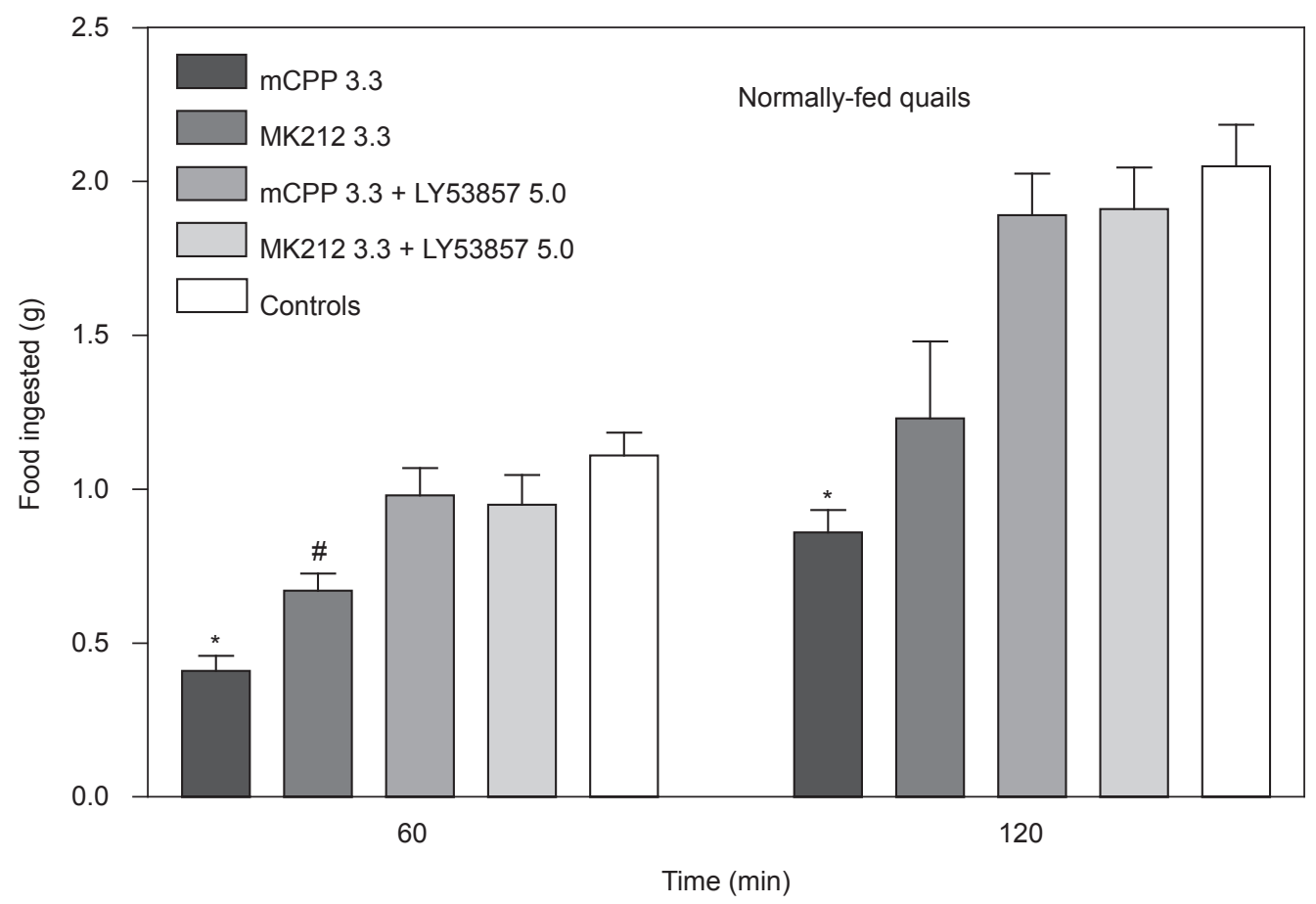

Fig. 5 - Effect of previous administration of 5-HT2C antagonist, LY53857 (5.0 mg/Kg, sc), on the food intake of normally fed quails treated with 5-HT2C serotonin agonists mCPP and MK212 (1.0 and 3.3 mg/Kg for each agonist, sc). Data represent mean \pm SEM. $* \mathrm{P}<0.0001$ and $\# \mathrm{P}<0.01$ compared with controls.

phylogenically ancient and are implicated in the control of adaptive functions during increased afflux of metabolic/nutritional and viscerosensory signals to the brain.

Current data allow us to postulate that the functional characteristic of the neuronal system of serotonin transmission, namely serotonin release, and 5-HT2C postsynaptic activation, have been preserved from birds to mammals.

Acknowledgments - The authors gratefully acknowledge FAPERJ and PIBIC/CNPq (Brazil) for their financial support of this work.

\section{REFERENCES}

Aghajanian, G. K., SPRouSE, J. S., SHELdON, P. \& RASMUSSEN, K., 1990, Neuropharmacology of serotonin: Electrophysiology of the central serotonin system. Receptor subtypes and transducer mechanisms. Ann. N. Y. Acad. Sci., 600: 93-103.

BLUNDELL, J. E., 1984, Serotonin and appetite. Neuropharmacology, 23: 1537-1551.
BLUNDELL, J. E. \& HILL, A. J., 1987, Nutrition, serotonin and appetite: Case study in the evaluation of a scientific idea. Appetite, 8: 183-194.

BLUNDELL, J. E., 1991, Pharmacological approaches to appetite suppression. TIPS, 12: 147-157.

CHALlET E., MiCEli D., PIERRE J., REPERANT J., MASICOTTE G., HERBIN M. \& VESSELKIN N. P., 1996, Distribution of serotonin-immunoreactivity in the brain of the pigeon (Columba livia). Anat. Embryol. (Berl), 193: 209-227.

COZZI B., VIGLIETTI-PANZICA C., ASTE N. \& PANZICA G. C., 1991, The serotoninergic system in the brain of the Japanese quail. An immunohistochemical study. Cell Tissue Res. 263: 271-284.

CURZON, G., 1990, Neuropharmacology of serotonin: Serotonin and Apetite. Ann. N. Y. Acad. Sci., 600: 521-531.

CURZON, G., 1991, Effects of tryptophan and of 5-hydroxytryptamine receptor subtype agonists on feeding. Adv. Exp. Med. Biol., 294: 377-388.

DOURISH, C. T., HUTSON, P. H., KENNETT, G. A. \& CURZON, G., 1986, 8-OH-DPAT induced hyperphagia: Its neural basis and possible therapeutic relevance. Appetite, 7(Suppl): 127-140.

DUBÉ, L. \& PARENT, A., 1981, The monoamine containing neurons in avian brain: I. A study of the brain stem of the chicken (Gallus domesticus) by means of fluorescence and 
acetylcholinesterase histochemistry. J. Comp. Neurol., 196: 695-708.

DUCHALA, C. S., OTTINGER, M. A. \& RUSSEK, E., 1984, The developmental distribution of monoamines in the brain of male Japanese quail (Coturnix coturnix japonica). Poult. Sci., 63: 1052-1060.

FERNSTROM, J. D. \& WURTMAN, R. J., 1971a, Brain serotonin, content: Increase following ingestion of carbohydrate diet. Science, 174: 1023-1025.

FERNSTROM, J. D. \& WURTMAN, R. J., 1971b, Brain serotonin content: Physiological dependence on plasma tryptophan levels. Science, 73: 149-152.

FERNSTROM, J. D., 1983, Role of precursor availability in control of monoamine biosynthesis in brain. Physiol. Rev., 63: 484-546.

GLEESON, S., WEISSMAN, B. A., SEGGEL, M. R. \& BARRET, J. E., 1992, Neurochemical effects of 5-HT1 receptor ligands in pigeons. Eur. J. Pharmacol., 229: 109-115.

GRUSS, M. \& BRAUN K., 1997, Distinct activation of monoaminergic pathway in chick brain in relation to auditory imprinting and stressful situations: a microdyalisis study. Neuroscience, 76: 891-899.

HALFORD, J. C. \& BLUNDELL, J. E., 2000, Serotonin drugs and the treatment of obesity, pp. 155-176. In: M.D. Lockwood \& T.C. Heffner (eds.), Obesity: Pathology and Therapy, Springer-Verlag, Berlin.

HALFORD, J. C. LAWTON, C. L. \& BLUNDELL, J. E., 1997, The 5-HT2C receptor agonist. MK212 reduces food intake and increases resting but prevents the behavioral satiety sequence. Pharmacol. Biochem. Behav., 56: 41-46.

HUTSON, P. H., DOURISH, C. T. \& CURZON, G., 1986, Neurochemical and behavioral evidence for mediation of the hyperphagic action of 8-OH-DPAT by 5 -HT cell body autoreceptors. Eur. J. Pharmacol., 129: 347-352.

HUTSON, P. H., DOURISH, C. T. \& CURZON, G., 1988, Evidence that the hyperphagic response to 8-OH-DPAT is mediated by 5-HT1A receptors. Eur. J. Pharmacol., 150: 361-3366.

MELTZER, H. Y. \& LOWY, M. T., 1987, Psychopharmacology. The Third Generation of Progress: The serotonin hypothesis of depression, pp. 513-523 In: Meltzer, H.Y. (ed), Raven Press, New York.
PARENT, A., 1981, Comparative anatomy of serotoninergic systems. J. Physiol. (Paris), 77: 147-156.

PARENT, A., DESCARRIES, L. \& BEAUDET, A., 1981, Organization of ascending serotonin systems in the adult rat brain. A radioautographic study after intraventricular administration of $\left[{ }^{3} \mathrm{H}\right] 5$-hydroxytryptamine. Neuroscience, 6: $115-138$.

REIS, L. C., ALMEIDA, A. C., CEDRAZ-MERCEZ, P. L., OLIVARES, E. L., MARINHO JR, A. \& THOMAZ, C. M, 2005, Evidence of the participation of serotonergic system in the control of feeding behavior in Coturnix japonica (Galliformes: Aves). Braz. J. Biol., 65(2): 353-361.

ROSEBROUGH, R. W., 1996, Crude protein and supplemental dietary tryptophan effects on growth and tissue neurotransmitter levels in the broiler chicken. Brit. J. Nut., 76: 87-96.

SAADOUN, A. \& CABRERA, M. C., 2002, Effect of the 5-HT1A receptor agonist 8-OH-DPAT on food and water intake in chickens. Physiol. Behav., 75: 271-275.

SAKO, H., KOJIMA, T., OKADO, N., 1986, Immunohistochemical study on the development of serotoninergic neurons in the chick: I. Distribution of cell bodies and fibers in the brain. J. Comp. Neurol. 253: 61-78.

SHIMIZU, N., TAKE, S., HORI, T. \& OOMURA, Y., 1992, In vivo measurement of hypothalamic serotonin release by intracerebral microdyalisis: Significant enhancement by immobilization stress in rats. Brain Res. Bull., 28: 727-734.

STEFFENS, S. M., CASAS, D. C., MILANEZ, B. C., FREITAS, C. G., PASCHOALIINI, M. A. \& MARINO-NETO, J., 1997, Hypophagic and dipsogenic effects of central 5-HT injections in pigeons. Brain Res. Bull., 44: 681-688.

STEPHENSON, R. M. \& ANDREW, R. J., 1994, The effects of 5-HT receptor blockade on memory formation in the chick. Pharmacol. Biochem. Behav., 48: 971-975.

THOMAZ, C. M., ALMEIDA, A. C., OLIVARES, E. L., BADAUÊ-PASSOS, D. Jr, MARINHO, A. Jr \& REIS, L. C., 1998, Influência do tratamento com precursores da serotonina no comportamento ingestivo de codornas (Coturnix japonica). Resumos da XIII Reunião Anual da FeSBE, Caxambu, MG, p. 53.

TYCE, G. M., 1990, Origin and metabolism of serotonin. $J$. Cardiovasc. Pharmacol., 16: S1-S7. 